\title{
Life cycle assessment application in the fruit sector: State of the art and recommendations for environmental declarations of fruit products
}

\author{
Alessandro K. Cerutti a, e, *, Gabriele L. Beccaro a , Sander Bruun ${ }^{\text {d }}$, Simona Bosco ${ }^{\text {b, e }}$, \\ Dario Donno ${ }^{a}$, Bruno Notarnicola ${ }^{c,}$, Giancarlo Bounous ${ }^{\text {a }}$ \\ a Department of Agriculture, Forestry and Food Science, University of Torino, Via Leonardo da Vinci, 44, 10095 Grugliasco, TO, Italy \\ ${ }^{\mathrm{b}}$ Institute of Life Sciences, Scuola Superiore S. Anna, Piazza Martiri della Libertà 33, 56127 Pisa, Italy \\ c Ionian Department, University of Bari Aldo Moro, Via Lago Maggiore angolo via Ancona, 74121 Taranto, Italy \\ ${ }^{\mathrm{d}}$ Department of Agriculture and Ecology, Faculty of Life Sciences, University of Copenhagen, Denmark \\ e Italian LCA Network, Italy
}

\section{A R T I C L E I N F O}

\section{Article history:}

Received 21 March 2013

Received in revised form

20 August 2013

Accepted 12 September 2013

Available online 21 September 2013

\section{Keywords:}

Fruit products

Orchard

Sustainable production

System boundaries

Functional unit

System modelling for impact assessment

\begin{abstract}
A B S T R A C T
Modern food production is very diverse with high levels of specialisation and complexity. These features inevitably reflect on methods in the application of LCA to food products and agro-systems. System boundaries, functional units, allocation procedures and several other aspects contribute to there being substantial differentiation in the structure of LCA applications in fruit production systems, leading to significantly different results. Indeed, although scientific literature on the topic is recent and not particularly extensive, there are already many different ways of conducting LCAs in orchards.

The aim of this paper is to propose a framework for selecting the best parameters for an LCA application in fruit production systems according to the objective of the study. This has been achieved by reviewing the scientific and technical literature on the topic. In particular papers from international journals and conference proceedings have been considered and the review has covered all main aspects for conducting an LCA in fruit production systems. The particular characteristics considered were objectives, system boundaries, the product considered, the functional unit, data origin and the environmental impact assessment method used.

A substantial part of the paper is devoted to the modelling of the orchard, as this is key to a reliable application of any impact assessment approach. Rather than merely describing the theoretical model, this paper presents concrete recommendations about how to build the orchard system for LCA application avoiding over or under-estimations of the different orchard stages.
\end{abstract}

(c) 2013 Elsevier Ltd. All rights reserved.

\section{Introduction}

In 2010, world production of fruit was 609,213,512 t, mostly concentrated in Asia (52\%) and America (22\%) (FAOSTAT, 2012). In Europe, $67,254,709 \mathrm{t}$ of fruit were produced, corresponding to around $11 \%$ of the fruit produced in the world, with significant contributions by Italy (25.14\% of the fruit produced in Europe), Spain $(22.57 \%)$ and France (12.93\%). The important role played by the Asian markets is even more evident from analysing production trends over the past 10 years: while America, Europe, Africa and Oceania record fairly constant fruit production, in Asia it has

\footnotetext{
* Corresponding author. Department of Agriculture, Forestry and Food Science, University of Torino, Via Leonardo da Vinci, 44, 10095 Grugliasco, TO, Italy.

E-mail addresses: alessandrokim.cerutti@gmail.com, alessandro.cerutti@unito.it (A.K. Cerutti).
}

increased by about 55\%, making China and India the highest producers of fruit in the world, with $20.06 \%$ and $13.92 \%$ of world production respectively.

Fruit products are generally considered to have a lower environmental impact potential than most foods in western diets. For example, Carlsson-Kanyama et al. (2003) quantified the energy consumption of different diets and reported an average of $5 \mathrm{MJ}$ per $\mathrm{kg}$ of in-season fruit (26 MJ per kg of out-of-season fruit), $15 \mathrm{MJ}$ per $\mathrm{kg}$ of vegetables, $17 \mathrm{MJ}$ per $\mathrm{kg}$ of bread and flour products, $33 \mathrm{MJ}$ per $\mathrm{kg}$ of dairy products, $37 \mathrm{MJ}$ per $\mathrm{kg}$ of meat and $75 \mathrm{MJ}$ per $\mathrm{kg}$ of fish products. On the other hand, compared to other food products, fruit production is considered to be an intensive agricultural system in terms of inputs of pesticides and fertilisers as well as investments in capital and material (e.g. Mouron et al., 2006a). Indeed the embodied energy of orchard infrastructures, such as hail nets and irrigation pipes, is higher than in other cropping systems. 
Furthermore, studies examining the carbon footprint of different food choices have reported that fruit is the food category with the lowest environmental impact potential (e.g. Wallén et al., 2004; Berners-Lee et al., 2012). However, these studies use data from environmental assessments of generic fruit production which do not take into account specific issues within orchard systems and fruit supply chains. Indeed, different results may arise in relation to the production system (e.g. conventional or organic), the production site (specific soil and climate conditions affecting yield and agronomic performances) or the retailing system (long-term cold storage may dramatically influence the environmental performance of the product). Recently Mouron et al. (2012) demonstrated that the same apple cultivation in five European regions may have completely different protection requirements, leading to very different environmental impacts.

High levels of specialisation, diversification and the complexity of orchard systems inevitably affect the methods involved in applying Life Cycle Assessment (LCA) to food products and agroecosystems (Notarnicola et al., 2012a). It is therefore important to study the work that has already been done regarding the standardisation of methods in order to make appropriate comparisons between products.

The main aim of the paper is to describe a reference framework for choosing the best settings for LCA applications in fruit production systems. In order to achieve this goal, recommendations are collected and discussed by undertaking a review of studies assessing LCA application in fruit production systems in scientific and technical literature. Furthermore, the secondary goals of the papers are: to identify aspects of fruit production that are of environmental importance according to the studies reviewed, to discuss harmonisation projects and to give practical recommendations about how to model orchards for LCA applications. Therefore Section 2 describes state-of-the-art practice in LCA in fruit production according to a literature review procedure described in 2.1. In this section both general and critical aspects are highlighted, such as the choice of the functional unit and ways of modelling the orchard. Section 3 moves from academic studies to environmental product declarations and harmonisation initiatives as important sources for highlighting practices in LCA application in the sector. In Section 4 recommendations and best practices are presented, with Section 4.1 in particular dealing with concrete descriptions of orchard modelling and 4.2 focussing on all other LCA settings for achieving the most reliable results according to the aim of the application.

\section{State-of-the-art LCA applied to fruit production}

\subsection{Academic literature review method}

In the review of LCA application in fruit systems, only peerreviewed papers from international journals and conference proceedings were considered. Studies that included the fruit production stage were selected by preference, while studies that considered the whole production of derivatives (e.g. fruit juice) were only included if they contributed to the analysis of the growth stage. The review covered all main aspects for conducting an LCA in fruit production systems. The specific characteristics considered were objectives, system boundaries, the products under consideration, functional unit, data origin and the environmental impact assessment method used.

After a preliminary study in the literature on LCA applications in the food sector, nine objectives were found to be the most common purposes of LCAs in the fruit sector. These objectives were: 1) to profile the environmental burden of a fruit product, in which a specific production system is evaluated and results are related to the case study without any intention of generalising; 2) to identify the environmental hotspots in production systems performance considering the different field operations and stages of the system; 3) to describe management strategies to improve environmental performance, a focus usually applied after objective 2 in order to give practical suggestions after the evaluations; 4) to compare the environmental burden of different food products on a common functional unit, e.g. a specific unit of nutrient content; 5) to compare different farming practices, e.g. organic and conventional; 6) to compare different environmental assessment methods such as LCA, ecological footprint analysis and water footprint in the same case study; 7) to profile the environmental burden of production in a given area by applying the LCA evaluation to a statistical database on farms in that specific area; 8) to evaluate the environmental properties of a supply chain, usually with the focus on differences in environmental impact for long and short distances between production and consumption sites; and 9) to assess a preliminary study for statistical investigations. In this case the LCA results were used with the outcomes of other indicators to develop complex indices.

\subsection{General aspects}

A total of 19 studies were identified: 11 articles in ISI journals and eight papers in proceedings from the LCA congress series (Table 1).

\subsubsection{General aspects of the cases studied}

With the exception of rare pioneering studies, it can be assumed that mainstream research on the LCA applied to fruit production systems began in around 2005. A number of papers were published in 2010 in conjunction with the 7th International Conference on LCA in the Agri-Food Sector, following the increasing trend of participation in congresses relating to LCAs of food (Notarnicola et al., 2012b). Despite the high quantity of fruit produced in Asia, most of the LCA applications published internationally focus on case studies in Europe and South America, and just one study focuses on China (Liu et al., 2010). It is therefore realistic to assume that in coming years, there will be more research on this subject on the Asian continent, both for case studies and for the environmental evaluation of fruit commercialisation.

\subsubsection{Objectives}

Most papers in the literature state more than one objective, with the exception of studies on the supply chain (objective 8) which usually focus on this aspect alone (e.g. Blanke and Burdick, 2005), even if they also investigate the field phase of the production process (e.g. Knudsen et al., 2011). A description of the environmental burden of the product (objective 1) is the prime objective of all studies, but it is often not the main objective, which may instead be a comparison of different methods (e.g. Cerutti et al., 2010). Suggestions on ways of being more sustainable (objective 3 ) are often associated with the evaluation of environmental hotspots (e.g. Cudjoe Adebah et al., 2010). The comparison of different methods is not usually applied to fruit production; it can only be found in comparisons of LCA with Ecological Footprint Analysis (Cerutti et al., 2010) and LCA with PAS 2050 (McLaren et al., 2010).

\subsubsection{Data origin}

Most of the studies reviewed (11 papers) are based on data collected from commercial orchards, either directly in field surveys or with questionnaires or interviews with farmers. Sometimes the approaches are a mix of these and the data collection method used for the different data in the study is not always clearly described. Four studies investigate commercial orchards and then compare the field dataset obtained with reference values. This approach allows conclusions to be drawn about specific orchards, while the 
Table 1

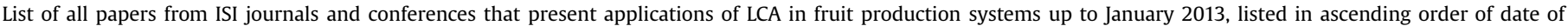

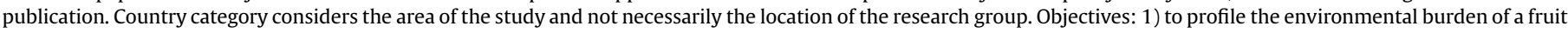

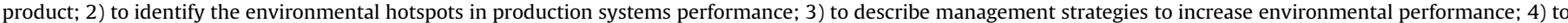

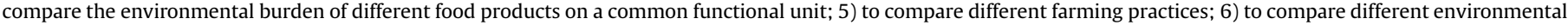

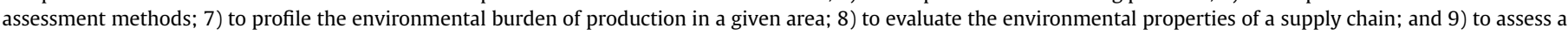
preliminary study for statistical investigations.

\begin{tabular}{|c|c|c|c|c|c|c|c|}
\hline Reference & Country & Product & $\begin{array}{l}\text { Main } \\
\text { objectives }\end{array}$ & Functional unit & Boundaries & Dataset & Assessment method \\
\hline $\begin{array}{l}\text { Blanke and } \\
\text { Burdick, } 2005\end{array}$ & $\begin{array}{l}\text { Germany, } \\
\text { New Zealand }\end{array}$ & Apple & 8 & Mass-based (kg) & Cradle-to-market & $\begin{array}{l}\text { Literature and } \\
\text { other databases }\end{array}$ & $\begin{array}{l}\text { Characterisation factors } \\
\text { from literature }\end{array}$ \\
\hline Sanjuan et al., 2005 & Spain & Orange & $1,2,7$ & Mass-based (kg) & Cradle-to-gate & $\begin{array}{l}\text { Literature and } \\
\text { other databases }\end{array}$ & CML, WMO, POPC and USES \\
\hline $\begin{array}{l}\text { Milà I Canals } \\
\text { et al., } 2006\end{array}$ & New Zealand & Apple & $1,2,3$ & Mass-based (t) & Cradle-to-market & $\begin{array}{l}\text { Commercial } \\
\text { orchards + validation }\end{array}$ & EDIP1997 \\
\hline $\begin{array}{l}\text { Mouron } \\
\text { et al., 2006a,b }\end{array}$ & Switzerland & Apple & $1,2,3,7$ & $\begin{array}{l}\text { Land-based (ha); } \\
\text { currency-based (\$) }\end{array}$ & Cradle-to-gate & Commercial orchards & SALCA (2003) \\
\hline $\begin{array}{l}\text { Milà i Canals } \\
\text { et al., } 2007\end{array}$ & UK, New Zealand & Apple & 8 & Mass-based (kg) & Cradle-to-market & $\begin{array}{l}\text { Literature and } \\
\text { specific databases }\end{array}$ & $\begin{array}{l}\text { Characterisation factors } \\
\text { from literature }\end{array}$ \\
\hline Sim et al., 2007 & $\begin{array}{l}\text { Brazil, Chile, } \\
\text { Italy, UK }\end{array}$ & Apple & 8 & $\begin{array}{l}\text { Mass-based } \\
(\mathrm{t}, \text { just grade } 1)\end{array}$ & Cradle-to-retailer & $\begin{array}{l}\text { Literature and } \\
\text { specific databases }\end{array}$ & CML 2 Baseline 2000 \\
\hline Williams et al., 2008 & UK, Spain & Strawberry & 8 & $\begin{array}{l}\text { Mass-based } \\
\text { (t at distribution) }\end{array}$ & Cradle-to-market & $\begin{array}{l}\text { Literature and } \\
\text { specific databases }\end{array}$ & $\begin{array}{l}\text { Characterisation factors } \\
\text { from literature }\end{array}$ \\
\hline Beccali et al., 2009 & Italy & $\begin{array}{l}\text { Citrus-based } \\
\text { products }\end{array}$ & 1 & $\begin{array}{l}\text { Mass-based } \\
\text { (kg of juices and oil) }\end{array}$ & Cradle-to-market & $\begin{array}{l}\text { Primary data from } \\
\text { field and secondary } \\
\text { from literature }\end{array}$ & $\begin{array}{l}\text { IPCC } 2001 \text { GWP100; } \\
\text { CML } 2 \text { Baseline } 2000\end{array}$ \\
\hline Coltro et al., 2009 & Brazil & Orange & 1,7 & Mass-based (t) & Cradle-to-gate & Commercial orchards & $\begin{array}{l}\text { Characterisation factors } \\
\text { from literature }\end{array}$ \\
\hline Beccali et al., 2010 & Italy & $\begin{array}{l}\text { Citrus-based } \\
\text { products }\end{array}$ & 3 & $\begin{array}{l}\text { Mass-based } \\
\text { (kg of juices and oil) }\end{array}$ & Cradle-to-market & $\begin{array}{l}\text { Primary data from } \\
\text { field and secondary } \\
\text { from literature }\end{array}$ & $\begin{array}{l}\text { IPCC } 2001 \text { GWP100; } \\
\text { CML } 2 \text { Baseline } 2000\end{array}$ \\
\hline Cerutti et al., 2010 & Italy & Peach & $1,2,6$ & Mass-based (kg) & Cradle-to-gate & $\begin{array}{l}\text { Commercial } \\
\text { orchards + validation }\end{array}$ & Eco-Indicator 99 \\
\hline $\begin{array}{l}\text { Cudjoe Abedah } \\
\text { et al., } 2010\end{array}$ & Ghana & Pineapple & 2,3 & Mass-based (kg) & Cradle-to-gate & Commercial orchards & $\begin{array}{l}\text { Characterisation factors } \\
\text { from literature }\end{array}$ \\
\hline Ingwersen, 2010 & Costa Rica & Pineapple & 1,9 & $\begin{array}{l}\text { Mass-based } \\
\text { (serving portion) }\end{array}$ & Cradle-to-retailer & Commercial orchards & Ecoinvent 2.0 \\
\hline Liu et al., 2010 & China & Pear & 2,8 & Mass-based (t) & Cradle-to-market & Commercial orchards & IPCC 2007 \\
\hline $\begin{array}{l}\text { Clasadonte } \\
\text { et al., 2010a }\end{array}$ & Italy & Peach & 4 & Mass-based (kg) & Cradle-to-gate & Commercial orchards & Impact $2002+$ \\
\hline $\begin{array}{l}\text { Clasadonte } \\
\text { et al., 2010b }\end{array}$ & Italy & Orange & 1,3 & Mass-based (kg) & Cradle-to-gate & Commercial orchard & Impact $2002+$ \\
\hline McLaren et al., 2010 & New Zealand & Apple, kiwifruit & $1,3,6$ & Mass-based (kg) & Cradle-to-use & Commercial orchards & PAS 2050 \\
\hline Cerutti et al., 2011 & Italy & Apple & 8 & Mass-based (kg) & Cradle-to-market & $\begin{array}{l}\text { Retailer and } \\
\text { associated orchards }\end{array}$ & EDIP 1997 \\
\hline $\begin{array}{l}\text { Knudsen } \\
\text { et al., } 2011\end{array}$ & Brazil & Orange & 5,8 & $\begin{array}{l}\text { Mass-based } \\
\text { (l of juice); } \\
\text { Mass-based } \\
\text { ( } \mathrm{t} \text { of fruit) }\end{array}$ & $\begin{array}{l}\text { Cradle-to-market } \\
\text { Cradle-to-gate }\end{array}$ & $\begin{array}{l}\text { Commercial } \\
\text { orchards and statistics }\end{array}$ & $\begin{array}{l}\text { EDIP } 1997+\text { IPCC } 2007 \\
(\text { GHG); IMPACT2002+ (energy) }\end{array}$ \\
\hline
\end{tabular}

validation for identifying unusual agricultural practices is only of interest for the specific farm (e.g. Milà I Canals et al., 2006). The other method used to obtain statistically robust datasets is to include a large number of commercial orchards and to consider average values for these farms. Furthermore, data from statistically robust datasets should also provide information about the distribution of the data, such as standard deviation and skewness (Mouron et al., 2006b). Seven studies used literature and available databases in order to obtain data instead of surveying commercial orchards. By applying this approach it is possible to obtain more generic results, but it is impossible to consider site-specific differences between orchards.

\subsubsection{Environmental impact assessment method}

The use of different environmental impact assessment methods may lead to different conclusions. Across the 19 papers reviewed, the typical impact categories are the categories which quantify effects on ecosystems rather than those on resource consumption or human toxicity, with particular attention on the potential for global warming, eutrophication and acidification. Global warming potential is mainly related to the combustion of fuels and so considered a key indicator in studies involving a comparison of systems with different transport distances (e.g. Blanke and Burdick, 2005; Cerutti et al., 2011). Eutrophication and acidification are generally more related to the use of fertilisers and pesticides (Hauschild, 2000) and thus depend on the farming practices used and climate conditions.

When defining the impact categories for fruit production, it is vital to consider the typical environmental problems that may arise in orchards (Milà I Canals et al., 2006). Fruit is usually produced in temperate sunny regions because intense sun ray light increases the yield and improves fruit quality. However, these regions are also prone to water scarcity and losses of nutrients and pesticides to the surrounding environment. These effects can influence all impact categories, but in particular nutrient enrichment potential and acidification potential (Coltro et al., 2009) as well as human toxicity.

\subsection{Modelling orchard systems}

The construction of a good model of a system that can correctly describe the real system is of the utmost importance (e.g. Mouron et al. 2012). In this respect, a precise definition of system boundaries is essential. 
In the literature reviewed, the two most frequently used system boundaries are cradle-to-gate and cradle-to-market. In the cradleto-gate category, the environmental impacts are quantified for the production phase, including all upstream impacts up to the farm gate (eight papers). The cradle-to-market category includes studies in which the distribution and commercialisation phase is included in the assessment (nine papers). Two particular boundaries are cradle-to-retailer (two papers) in which processing and transport to the distribution system are included, and cradle-to-use (one paper) in which impacts from the consumer phase are also included. The nursery where orchard seedlings are produced should be considered an upstream process delivering grafted plants to the orchards and the impact during this stage should be included in assessments of fruit production systems even if impacts are spread over the lifetime of the orchard (see Section 2.4). However, although many authors stress that it is important to consider the nursery in environmental impact assessments (Milà I Canals et al., 2006; Cerutti et al., 2010), a lack of data makes this difficult.

For the purposes of efficient modelling of an orchard system, it is necessary to take into account two aspects:

(I) Orchards are biological systems. As for all other food production systems, the variability and unpredictability of living systems must be taken into account. Unlike industrial production, where the amount of commercial product is known and given as a reliable function of the inputs supplied, biological systems can have variable yields, depending on environmental conditions (biotic and abiotic). The strong dependence of biological production systems on weather conditions is also expressed as variations in the quantity of agricultural inputs needed to maintain production at the desired level. For example, in years with very high spring temperatures, the risk of pest attacks increases dramatically, with a consequent increase in agrochemical use (Sansavini et al., 2012) which affects both the impact on production and the impact on input losses (leaching for instance).

(II) Orchards are perennial systems. Unlike field crops, the life cycle of which is completed in under a year, fruit systems involve plants with very variable duration (10-30 years) depending on the crop and management practice. The long cropping cycle of orchards means that there are processes that occur once over the entire life cycle (e.g. during orchard establishment and disposal) and other processes that are repeated a number of times depending on the length of the cycle (e.g. pruning and fertilisation). Furthermore, most temperate fruit cultures reach maturity in two to four years after the orchard is established. Before that age, the yield may be significantly lower (or even zero) because the plants are still too young. This may significantly affect the average yield and has to be considered. Furthermore, the yield variability between years may be very high. For example, McLaren et al. (2010) reported that the highest yield for green kiwifruit over a period of six years was 31\% greater than the lowest.

These two characteristics add complexity to the modelling of fruit systems, but if the productive period alone is considered, the environmental impacts of the final product are underestimated considerably (Cerutti et al., 2010, 2011).

A detailed model of the fruit production system may take into account these two aspects by dividing the system into different stages (Fig. 1). This modelling approach was originally proposed by Milà I Canals et al., 2006 and later validated by Cerutti et al. (2010) and Cerutti et al., 2011. Six main stages have been considered in particular: (1) the nursery phase for producing rootstocks, scions and whips ready to plant, (2) planting and field preparation for the orchard, (3) the early low production phase due to the system's immaturity, (4) full production, (5) the low production phase due to plant senescence, and (6) the removal and disposal of plants. It should be noted that the final two stages are theoretical and are seldom found in commercial orchards in Europe since fruit growers replace the orchards at the end of stage 4 for economic reasons.

Considering this model, stages 1, 2 and 6 do not have output in commercial production, but may contribute to generating the product's environmental impacts. Stages 3, 4 and 5 are those in which fruit is produced and the annual output quantity may vary from year to year. Although it is very difficult to find data for production as a function of orchard age, it is recommended that average production data (measured or modelled) be used for each of stages 3-5 (Fig. 1).

\subsection{The nursery subsystem}

In the literature reviewed, little importance is given to the nursery. Just three studies assess the environmental impacts of the nursery as a stage within the whole production system. Although in

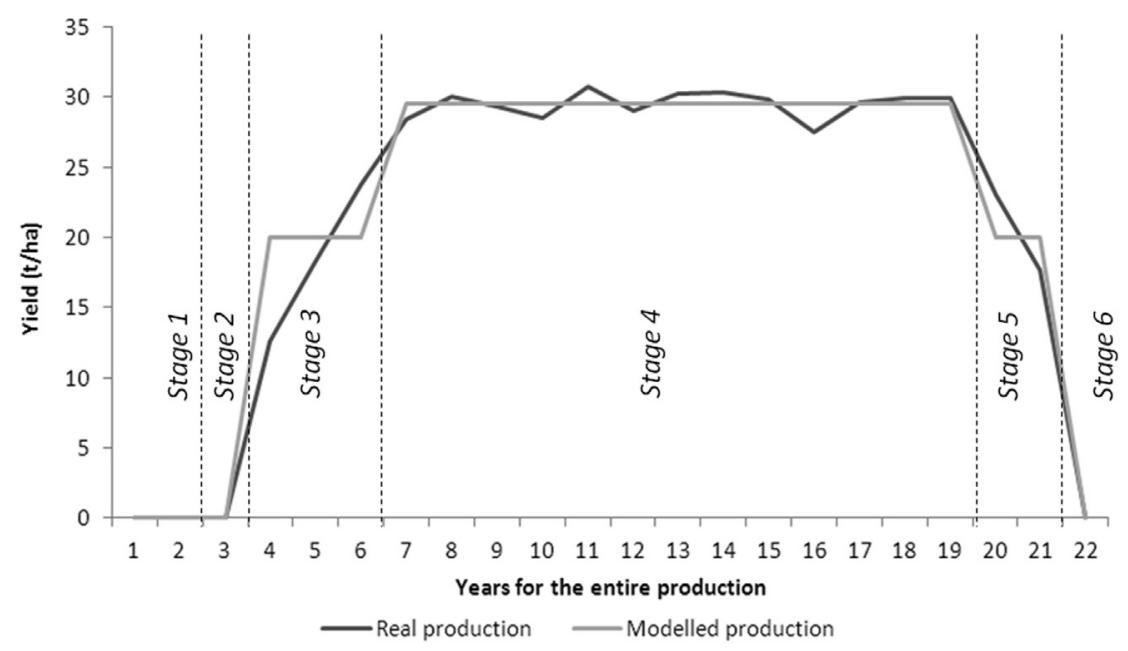

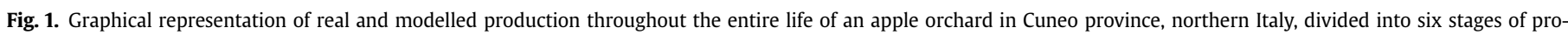
duction. Adapted from Cerutti et al. (2011) 


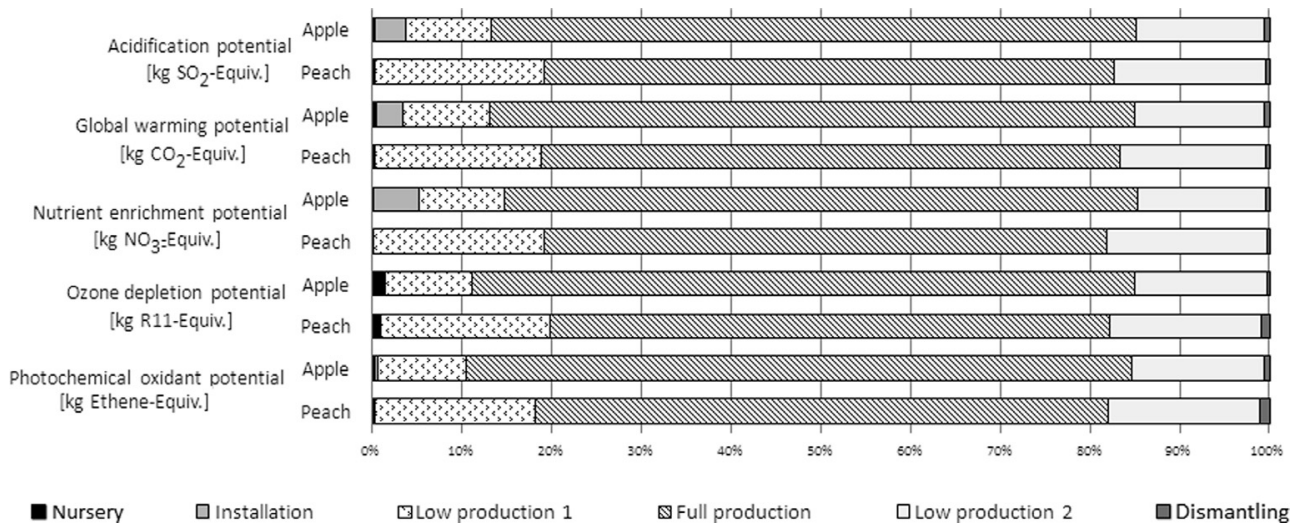

Fig. 2. Hotspot analysis of two previous case studies. Adapted from Cerutti et al. (2011)

some perennial plantation systems its relative contribution may be negligible (Yusoff and Hansen, 2007), the nursery stage may play an important role for plants that need special protection in the early stages, such as specific growth substrates (Ingram, 2012) or plastics for greenhouses (Russo and Scarascia-Mugnozza, 2005).

Due to all the nursery-related impacts, the application of an environmental indicator to the full production year only will probably underestimate the real environmental impact to a varying degree (in the studies reviewed here by about $30 \%$, depending on the fruit considered and the assessment method) (Fig. 3).

As the environmental impacts of the nursery stage are allocated per plant grafted or planted in the orchard, there is a strong relationship between the density of the plantation and the relative impact of the nursery (Cerutti et al., 2013). Although this relationship can be readily observed in comparative studies, owing to the small number of LCA studies on fruit that include the nursery stage, no significant correlation with the fruit species and the proportion of total impacts can as yet be identified.

Therefore adopting a fraction of field production impacts considering the theoretical duration and plant capacity of the nursery study as a proxy is a risky approach that should be avoided when reliable data or reference case studies are available. The only way of making up for the lack of knowledge is to increase the number of studies including the nursery stage and to include nursery average impacts in LCA databases and tools, as is already done for other inputs such as fertilisers and pesticides.

\subsection{Which functional unit to use?}

The functional unit helps quantify the productive output of the orchard in order to allow a comparison of different production systems. Fruits and fruit products may be of different quality and have different nutrient and economic values, and thus it may be difficult to find a useful functional unit. In most cases, however, there is not much debate about the definition of a functional unit (e.g. $1 \mathrm{~kg}$ of product). Several different units are used in the 19 papers reviewed here and these can be categorised into three different types:

(i) Mass-based functional units where the environmental impacts are related to a specific quantity of products produced. In total there are 18 applications of this type of functional unit in the papers reviewed here. Environmental impacts are usually related to the production of one metric tonne of fruit if the system boundaries focus on the farm gate, or the production of $1 \mathrm{~kg}$ of fruit if a cradle-to-table approach is used. When using a mass-based functional unit, problems may arise in how to account for fruit quality (Milà I Canals et al.,

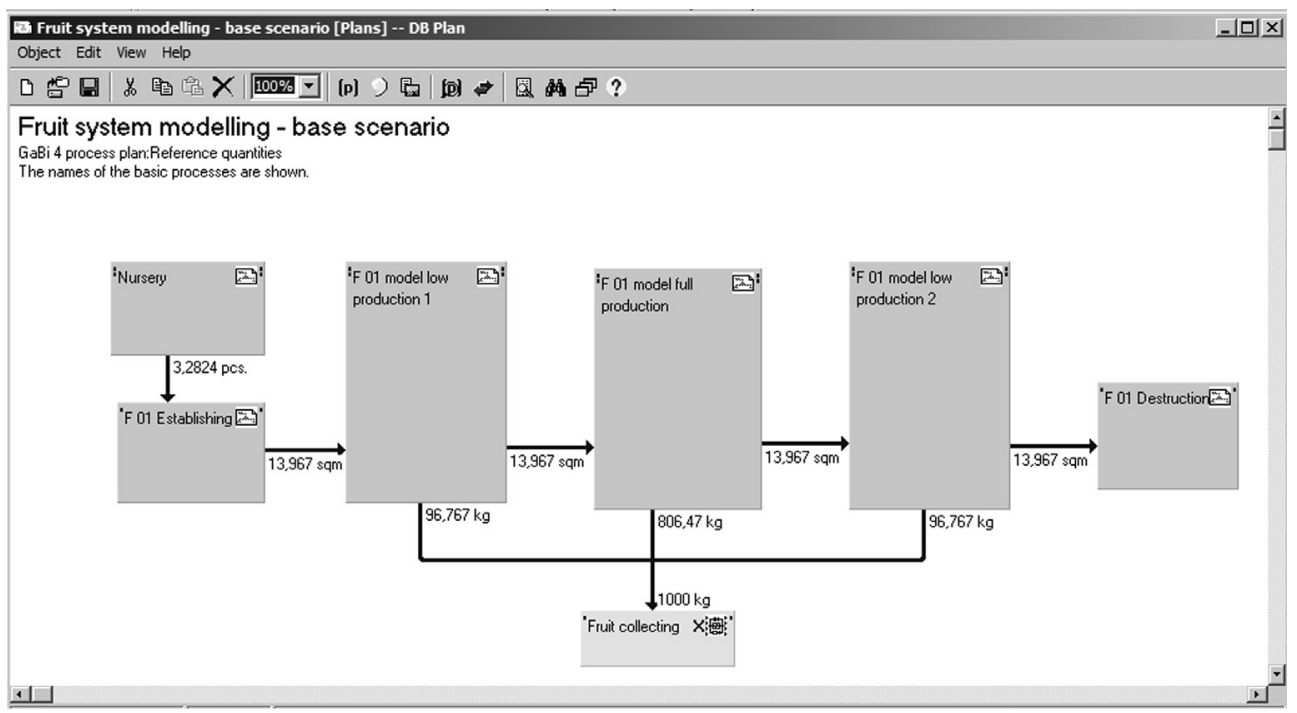

Fig. 3. Orchard life cycle modelling in Gabi 4.0. 
2006). The same orchard can usually produce fruit of different quality (e.g. size, colour, firmness or sugar content) targeted at different markets (e.g. the fresh market or industrial processing). Although the chemical and fiscal properties of fruit are not sufficient to define quality, the functional unit can be defined to include the obligatory product properties required by the market segment (Peacock et al., 2011)

Looking at environmental impacts per unit mass of product alone evaluates the eco-efficiency of the production but not its sustainability because efficiency does not necessarily lead to sustainability (Wackernagel and Rees, 1997; van der Werf et al., 2007). Furthermore the same increase of efficiency that contributes to a higher income can be negatively correlated to environmental impacts (Mouron et al., 2012).

(ii) Land use-based functional units where the environmental impacts are related to the management of 1 ha of orchard. A land-based and currency-based functional unit is used in just one of the studies reviewed (Mouron et al., 2006b). The land use-based functional unit, such as 1 ha of orchard, is not frequently used in LCA, partly because land use is not a service and does not provide a productive function, even if land suitable for fruit production is often rare. In fact, it makes more sense to consider land use to be an environmental impact in an LCA. However, land use is an integrated line of thinking in an agronomic setting and can produce interesting results. In general, converting resource consumption or environmental impacts to units of land use allows the impacts of cultivating a certain area to be evaluated. This parameter is also called a farm's impact intensity (Mouron et al., 2006b). The land use-based functional unit in fruit production is complementary to the mass-based functional unit because they give different results and both should be used. Indeed, when considering impacts per unit area alone, low input-output systems will have a better ranking for decreased impacts at a regional level. From a life cycle perspective, however, they create a need for additional land use to produce a quantity of products similar to the high input-output systems, leading to additional impacts (van der Werf et al., 2007).

Furthermore, the use of a mass-based or a land-based functional unit reflects the perspective addressed by the particular study: the former is used in a product-orientated expression of agricultural production and the latter in a land-orientated expression (Hayashi, 2013). Furthermore, the land-based functional unit represents the land-management function of agriculture (Nemecek et al., 2011).

(iii) Economic value-based functional units where the environmental impacts are related to a particular amount $(€)$ of grower income from wholesale fruit sales. It is used in one application in the papers that have been reviewed. This functional unit is useful because it integrates product quantity and quality in a single measure (Mouron et al., 2006b), but is strongly influenced by the economic context in which the farm is located and can change significantly from one year to the next. Therefore the reference period should be several years. In Mouron et al. (2006b) four years were taken into account because of the characteristics of fruit production in which high production and low production years are alternated (biennial bearing).

A recent study (Cerutti et al., 2013) points out that comparing the same fruit production systems with different functional units may lead to completely different scenarios. In particular, fruit cultivars with a higher yield show a significantly better environmental performance using a mass-based functional unit, while fruit cultivars with a lower yield are favoured by a land use-based functional unit (Cerutti et al., 2013). That study also shows that different functional units used in LCA actually address different research questions, so the scope of the research needs to be carefully described.

Another important aspect in the study of the most suitable functional unit for fruit production is the problem of food waste. Indeed, as most fruit perishes rapidly, quantification of product loss in the supply chain is needed in order to evaluate the environmental impact of the product actually consumed (Ingwersen, 2010). This aspect is crucial for assessments that include the market or consumer phase in their boundaries. Indeed for a specified unit of product sold or consumed there is a specific amount (or an average range of an amount) that is wasted. Nevertheless in a strictly productive framework when a cradle-to-gate assessment is adopted, the aspect of food waste has not been addressed in the papers considered.

\section{LCA of fruit product in technical reports and international initiatives}

\subsection{Environmental declarations of fresh fruit and fruit products}

LCA approaches are now considered to form the basis for communicating the overall environmental performance of products (Ingwersen and Stevenson, 2012) and there are several frameworks for Environmental Product Declarations (EPDs). One of the most widely used declaration systems to include the LCA of food products is the international EPD ${ }^{\circledR}$ System, standardised as type III labelling (ISO 14025). This declaration system works with rules based on a hierarchical approach following the international standards ISO 9001, ISO 14001, ISO 14040, ISO 14044 and ISO 21930. As a consequence, the LCA approach is a mandatory procedure and reference is made to LCA-based information as content for consideration for product category rules (PCRs). According to the definition (Del Borghi, 2013), PCR documents define the requirements for the EPDs of a certain product category and allow transparency and comparability between different EPDs based on the same PCR. In fact these requirements are developed in collaborative frameworks with industries, research institutes and universities in order to achieve the best comparability of results between different producers of the same product.

Another important international framework for EPDs is the Product Environmental Footprint (PEF) which is a LCA-based method to calculate the environmental performance of a product. It was developed by the European Commission's Joint Research Centre and is based on existing methods that have been tested and used extensively (European Commission, 2013). In this framework Product Environmental Footprint Category Rules (PEFCRs) are used but, up to now, the protocol covers the testing phase and as yet there are no PEFCRs for fruit.

In the International EPD ${ }^{\circledR}$ system, fruit products are covered by a general PCR (Fruits and nuts - 2012:07) for the sector and five other specific PCRs (see Table 2 for details). These documents attempt to merge theoretical aspects to provide a scientifically sound assessment of the impacts and practical aspects in collecting data and managing the assessment. Indeed, the amount of work required to collect high-quality data has been recognised as a major obstacle in the production of PCRs by small and medium-sized businesses (SMEs) (Zackrisson et al., 2008).

In the general PCR for fresh fruits, it is recognised that standard sampling is quite unlikely to render a representative yield in $\mathrm{kg}$ of product per hectare or the yield factor per square metre of cropland required to produce $1 \mathrm{~kg}$ of product (Fruits and nuts - 2012:07 p. 10, Section 7.4). Therefore three options are given: (a) adopting a typical yield factor $\left(\mathrm{m}^{2} / \mathrm{kg}\right)$ previously agreed between the interested parties in the area under evaluation, based on agronomic parameters 
Table 2

Description of all the PCRs (and relative EPDs) which consider fruit products, fresh and transformed, registered in the EPD ${ }^{\circledR}$ system.

\begin{tabular}{|c|c|c|c|c|c|}
\hline PCR name & PCP product code & Moderator & Status & Related EPD & EPD code \\
\hline Fruits and nuts & $\begin{array}{l}\text { Group 013: Fruits and nuts, } \\
\text { and the following classes } \\
\text { Class 0131: Tropical and } \\
\text { subtropical fruits } \\
\text { Class 0132: Citrus fruits } \\
\text { Class 0133: Grapes } \\
\text { Class 0134: Berries } \\
\text { Class 0135: Pome fruits } \\
\text { and stone fruits } \\
\text { Class 0136: Fruit seeds } \\
\text { Class 0137: Nuts } \\
\text { Class 0139: Other fruits n.e.c. }\end{array}$ & $\begin{array}{l}\text { George Michalopoulos } \\
\text { RodaxAgro LTD }\end{array}$ & Completed & $\begin{array}{l}\text { Apples from } \\
\text { Trentino-Alto Adige }\end{array}$ & S-P-00369 \\
\hline Kiwifruit & Class 01342: Kiwifruit & $\begin{array}{l}\text { John Andrews Landcare } \\
\text { Research, New Zealand }\end{array}$ & Completed & $\begin{array}{l}\text { Kiwifruit produced } \\
\text { by Zeus Kiwi SA in Greece }\end{array}$ & S-P-00310 \\
\hline Fruit juices & Class 2143:Fruit juices & $\begin{array}{l}\text { Massimo Marino Life } \\
\text { Cycle Engineering Italy }\end{array}$ & Completed & - & - \\
\hline $\begin{array}{l}\text { Jams, fruit jellies } \\
\text { and marmalades }\end{array}$ & $\begin{array}{l}\text { Class 21494: Jams, fruit jellies, } \\
\text { marmalades, fruit or nut puree } \\
\text { and fruit or nut paste }\end{array}$ & $\begin{array}{l}\text { Assunta Filareto Life } \\
\text { Cycle Engineering }\end{array}$ & Completed & - & - \\
\hline $\begin{array}{l}\text { Other prepared and } \\
\text { preserved fruits and nuts }\end{array}$ & $\begin{array}{l}\text { Class 2149: Other prepared and } \\
\text { preserved fruits and nuts }\end{array}$ & $\begin{array}{l}\text { Adriana Del Borghi } \\
\text { Dpt Chem \& Process Engineering, } \\
\text { University of Genoa }\end{array}$ & Open consultation & - & - \\
\hline Table olives & Class 0145: Olives & $\begin{array}{l}\text { George Michalopoulos } \\
\text { RodaxAgro LTD }\end{array}$ & Under review & - & - \\
\hline
\end{tabular}

and historical data for the area; (b) sample inflows/outflows from orchards of the same fruit in a group of farms to obtain an average yield factor; or (c) considering every production period as a unique batch in EPD terms, in which case the period of validity of the EPD will cover only a single production period.

Regarding the choice of functional unit, no specific suggestions can be found in the general PCR, but it is recommended that allocations between grades of product be avoided. In particular, it is stated that where fruits and nuts are destined for human consumption, even though they may be of potentially different grades, they are considered equivalent in terms of the service they deliver so an allocation is not appropriate (Fruits and nuts - 2012:07 p. 9, Section 7.3.1). Nevertheless, the diversification of the supply for different grades of product from the same orchard is a very frequent procedure, with grade one fruit usually destined for the fresh market and other grades for industrial processing. Therefore, when considering a cradle-toconsumer approach, taking into account the impacts of the mass of fruit reaching the farm gate may produce misleading results.

\subsection{Harmonisation projects in an LCA of fruit production}

Up to now, different approaches and guidelines have been developed for harmonising methods in the calculation of the environmental impact of food production systems. In particular many guidelines have been developed with a specific focus on the GHG emissions from life cycle of goods and services, such as the Publicly Available Specification (PAS2050) developed by the British Standards Institute and the Carbon Trust (BSI, 2011; Carbon Trust, 2007), the French Bilan Carbone (ADEME, 2010), and the GHG Protocol drawn up by the World Resources Institute and the World Business Council for Sustainable Development (WBCSD/WRI, 2009). Two specific ISO standards on product carbon footprints, ISO 14067 (ISO, 2013a) and water footprints (ISO, 2013b), are currently being developed. What characterises most of these initiatives is the use of just one indicator (carbon or water). On the other hand, the European Commission's Joint Research Centre is developing the Product Environmental Footprint, a harmonised framework for assessing the sustainability of products which is expected to be in line with ISO standards on life cycle assessment and recognised scientific methodologies. Given the proliferation of standards and technical guides in the food and drinks sector, there was a particular focus on this sector with the establishment of the European Food Sustainable Consumption and Production Round Table in 2009. Within this broad framework the main stakeholders from food industries are also partners in order to promote a science-based, coherent approach to sustainable consumption and production in the European food sector across the whole life cycle (Peacock et al., 2011). The first attempt at a harmonised method for the environmental assessment of food and drink products is the European Food SCP Roundtable's Draft ENVIFOOD Protocol issued in 2013 (European Commission, 2012), which is currently being tested. The main objective is to provide guidance for assessments which are instrumental for both the communication and environmental improvement of business-to-business and business-toconsumer analyses (De Camillis et al., 2012).

The ENVIFOOD protocol includes a list of relevant impact categories for the environmental assessment of food and drink products and is expected to contain more detailed product footprint categories rules (PFCR) than the PCR in the EPD ${ }^{\circledR}$ scheme. Ideally, all relevant life cycle phases should be considered in the system boundary (i.e. the cradle-to-grave approach) and primary and secondary data should comply with ILCD Data Network entry-level requirements (European Commission, 2010). Particular attention in the definition of system boundaries is given to the use phase and waste management.

Fresh fruit in group 1 in the ENVIFOOD protocol are expected to be studied throughout the full life cycle, including the use phase if relevant in the PCR. Nevertheless there is no specific guidance on how to take the whole lifetime of orchard systems into account. Furthermore, according to the protocol, the impact categories relevant for agriculture and water consumption are to be reported separately.

\section{Main challenges and recommendations}

\subsection{A standard orchard model}

The three suggested options for estimating yields (using pre-set estimations, calculating an average or setting a timeframe of validity - see chapter 3.1) do not take into consideration the fact that major diseases or dramatic adverse climate conditions usually 
affect an entire production area at the same time, influencing the yield factor for the whole region (Sansavini et al., 2012). Furthermore recent research on olive orchards in Southern Italy (Notarnicola et al., 2013) has shown that statistically significant differences may occur in orchard management practices and farm performances at a regional level. As a consequence, using a local average of the yield factor might be a good solution for including the variability of orchard inflows/outflows in small areas, but not the variability at a regional level or within the timescale.

A possible way of avoiding this problem is to use the annual average of orchard inflows and outflows collected over a period of a particular number of years. Pirilli et al. (2012) suggested that three years might be sufficient but, owing to the alternation of production (biennial bearing) in most of the perennial crops in Europe, an even number of years should be adopted. A four-year time interval may be considered as a minimum requirement for data, but the optimum period of data collection should be based on a cropspecific literature review. Indirect field data may also be used to cover any missing years of sampling. For instance, in some countries farmers are asked by their regional authorities to keep field logbooks in which they record the main inflows and outflows of their orchards. This data can be used to provide a historical weighting of the yearly yield factor.

Furthermore, as an EPD is generally for three years, it is suggested that output data continues to be measured for the duration of the EPD. Further updating of the declaration (if requested) may provide historical references for a more balanced yield factor.

Even when full sets of field and historical data can be collected, recommendations may be needed for modelling the orchard system in LCA tools. To this end, the data reported in previous studies has been organised in GaBI 4.0 (PE International). In order to avoid calculation errors, six sub-systems (hereafter called plans, in line with operational terminology) have been created and connected as follows (Fig. 2):

Plan 1: Nursery. All processes and input materials used in the nursery stage can be accounted for using grafted plants to be planted in the orchard as the reference flow. Indeed this process represents the connection between the nursery plan and the following parts of the orchard system.

Plan 2: Establishment. In this plan all the processes that occur in the preparation of 1 ha of orchard must be included. The grafted plants are connected to the previous plan through the input of plants per hectare. Plan 2 has to lead to 1 ha of ready-to-produce orchard for connecting to the next plan.

Plan 3: Low production years (first part). The plan must include one sub-plan for each year of low production. Including one process for each year would correctly balance the weight of other processes that occur just once in the whole lifetime of the orchard (such as its establishment). Each of these sub-plans has to be connected through the reference flow of 1 ha of orchard and has to include an open output with the mass of fruit produced for that year. Each sub-plan considers the specific inflows and outflows of the reference year, i.e. the specific farming inputs and fruit yield. Data for these years may be obtained from field workbooks or may be modelled considering the fruit species and all the agricultural factors (see Section 2.3).

Plan 4: Full production years. This plan is connected to the previous one through the reference flow of orchard hectares. This plan must include one sub-plan for each year of full production which includes the specific inflows and outflows of the reference year, i.e. the specific farming inputs and the fruit yield. Inflows and outflows should be obtained through historical data or, for all years, can be considered to be the average of the data directly acquired from at least four full production years.
In this case too, each sub-plan has to be connected through the reference flow of orchard hectares, leaving the output of orchard hectares in the last year free to be connected to the next plan. In each year, the specific sub-plan for output of fruit produced has to be left open.

Plan 5: Low production years (second part). This plan follows the same rules as plan 4 according to the inflows and outflows of the second tail of the model describing the orchard's senescence. Specific data for these years are very rare, but information may be obtained directly from farm managers. It is not uncommon for the orchard to be removed from production at the first signs of lower production; in this case the low production stage can be avoided and plan 4 may be directly connected to plan 6 .

Plan 6: Dismantling. This plan follows the same rules as the establishment plan (2), with the exception of opening an input of orchard hectares in the first process to be connected to the previous plan and closing the output of orchard hectares in the final process because no further connections are required.

Once the six plans are completed and connected, one last process has to be added. This is a fictitious process called "fruit collecting" (Fig. 2) which is needed to connect the fruit outflows from the three production plans $(3-5)$ to a single output of fruit mass that can be fixed as the functional unit that best fits the case study (e.g. $1000 \mathrm{~kg}$ of fruit in Fig. 2). By applying this fictitious process, all the inflows are automatically scaled to the weight of harvested material at each stage. For example, in the case study reported in Fig. 2, for the functional unit of $1000 \mathrm{~kg}$ of fruit, impacts of the full production years are related to $96.76 \mathrm{~kg}$ of output from plan 3, plus $806.47 \mathrm{~kg}$ of output from plan 4 and $96.76 \mathrm{~kg}$ of output from plan 5 . Stages that occurred once in the whole life cycle of the orchard are scaled automatically. In the case study, the impacts of installation and dismantling are related to inflows and outflows of $13.96 \mathrm{~m}^{2}$ of orchard, which virtually represents the production area needed for the functional unit, weighted for the whole lifetime of the orchard. The same process occurs for the nursery, which is connected to the number of grafted plants installed in the "weighted" orchard area, thus depending on orchard density.

This model has been tested several times in order to avoid double counting or over and under-estimations of each production stage. However there may be other ways of modelling the whole life cycle of the orchard.

\subsection{Setting LCA parameters of application in fruit production systems}

Despite the general standardisation of phases in orchard management, great variability in farming practices and fruit products leads to different ways of applying the LCA in such systems (Bessou et al., 2013). Nevertheless, a standardised model for applying environmental assessment methods in fruit production is useful as a point of departure for more elaborate applications, otherwise results may be impossible to compare and risk not being included in the case study. The possibility of comparing the results from different studies would also allow sustainability thresholds to be identified, as suggested by several authors (e.g. van der Werf and Petit, 2002).

Suggestions for the standardisation of assessment method applications in fruit production according to the aim of the study are given in Table 3.

Moreover, in view of the fact that it is necessary to include the whole lifetime of the orchard within the system boundaries, the impacts from the nursery phase, orchard establishment and destruction should also be assessed. As orchards are not a single-year 
Table 3

Summary of recommendations for LCA properties according to the aims most frequently stated in the papers considered in this review.

\begin{tabular}{|c|c|c|c|c|}
\hline & $\begin{array}{l}\text { Profile of environmental } \\
\text { burdens of a product }\end{array}$ & $\begin{array}{l}\text { Profile of environmental } \\
\text { burdens of a supply chain }\end{array}$ & $\begin{array}{l}\text { Comparison of different } \\
\text { products or farming practices }\end{array}$ & $\begin{array}{l}\text { Profile of environmental } \\
\text { burdens of a production area }\end{array}$ \\
\hline $\begin{array}{l}\text { Data quality } \\
\text { requirement }\end{array}$ & $\begin{array}{l}\text { Field data collected in even number } \\
\text { of years (at least } 4 \text { ), literature data } \\
\text { should be avoided completely }\end{array}$ & $\begin{array}{l}\text { Field data collected in even } \\
\text { number of years (at least } 4 \text { ), } \\
\text { literature data can be used but } \\
\text { checked for consistency }\end{array}$ & $\begin{array}{l}\text { Field data collected in even } \\
\text { number of years (at least } 4 \text { ), } \\
\text { literature data can be used } \\
\text { but checked for consistency }\end{array}$ & $\begin{array}{l}\text { Field data collected in even } \\
\text { number of years (at least } 4 \text { ), } \\
\text { literature data should be } \\
\text { avoided completely }\end{array}$ \\
\hline $\begin{array}{l}\text { Number of } \\
\text { production sites } \\
\text { to be investigated }\end{array}$ & $\begin{array}{l}\text { At least } 3 \text { orchards per set } \\
\text { of agronomic parameters }{ }^{\mathrm{a}}\end{array}$ & $\begin{array}{l}\text { At least } 3 \text { orchards per set } \\
\text { of agronomic parameters }{ }^{\mathrm{a}}\end{array}$ & $\begin{array}{l}\text { At least } 3 \text { orchards per set of } \\
\text { agronomic parameters }^{\text {a }}\end{array}$ & $\begin{array}{l}\text { At least } 3 \text { orchards per set } \\
\text { of agronomic parameters }{ }^{\text {a }} \text {, } \\
\text { choosing sites furthest away } \\
\text { from one another }\end{array}$ \\
\hline $\begin{array}{l}\text { Suggested } \\
\quad \text { weighing method(s) }\end{array}$ & $\begin{array}{l}\text { Impacts of production sites } \\
\text { weighted by farm yield }\end{array}$ & $\begin{array}{l}\text { Impacts of production sites } \\
\text { weighted by farm yield }\end{array}$ & $\begin{array}{l}\text { Two sets of results: one based } \\
\text { on impacts of production sites } \\
\text { weighted by farm yield and } \\
\text { by farm dimension }\end{array}$ & $\begin{array}{l}\text { Production sites weighted by } \\
\text { farm dimensions }\end{array}$ \\
\hline System boundaries & Cradle-to-gate & Cradle-to-consumption & Cradle-to-gate & Cradle-to-gate \\
\hline Functional unit(s) & 1 tonne of final product & $\begin{array}{l}1 \text { portion of edible part } \\
\text { of the fruit }\end{array}$ & $\begin{array}{l}1 \text { tonne of final product, } 1 \text { ha } \\
\text { of orchard, } 1 \text { currency unit earned }\end{array}$ & $\begin{array}{l}1 \text { tonne of final product, } \\
1 \text { ha of orchard, }\end{array}$ \\
\hline Suggested further use & $\begin{array}{l}\text { Reference study for environmental } \\
\text { product declarations or databases }\end{array}$ & $\begin{array}{l}\text { Reference study for assessing } \\
\text { environmental burden of diets }\end{array}$ & $\begin{array}{l}\text { Reference study for greener } \\
\text { production design }\end{array}$ & $\begin{array}{l}\text { Reference study for } \\
\text { environmental product } \\
\text { declarations or databases }\end{array}$ \\
\hline
\end{tabular}

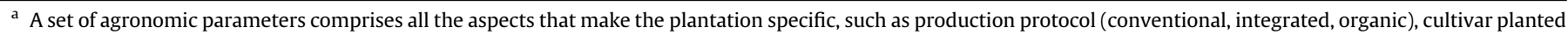
and soil type.

production system, the application of an environmental indicator to the full production year alone will probably underestimate the real ecological impact by a varying percentage (see Section 2.4).

As concluded in other reviews (Petti et al., 2010; Bessou et al., 2013), one of the most frequent problems in the environmental assessment of orchards is the difficulty in finding specific data and characterisation factors for pesticides and fertilisers. The fate and effects of chemicals in a particular orchard differ greatly depending on the pedo-climatic conditions in that orchard. Therefore, it is necessary to conduct the analysis using a predictive mathematical method which can either be used in multi-attributive approaches to complement Life Cycle Impact Assessment (LCIA) results, such as SYNOPS (Gutsche and Rossberg, 1997; Strassemeyer and Gutsche, 2010) or to model pesticide dispersion for direct integration into LCIA results, such as PestLCI (Birkved and Hauschild, 2006; Dijkman et al., 2012). In this way, the orchard is considered part of the technosphere. An alternative method is to consider the orchard as part of the environment or natural system and assume that emissions arise as soon as pesticides are sprayed with their fate then modelled using characterisation factors. These approaches lead to different results in the assessment, with potentially dramatic effects in comparisons between studies. Similar considerations can be made when evaluating the impact of using fertilisers. In this regard two approaches are usually applied: use of a detailed orchard model or use of a nutrient balance in which impacts of distribution are related to the effects of the surplus nutrient on the environment (Milà I Canals et al., 2006). The latter approach requires specific agronomic investigations about the nutrient demand of the plants and the nutrient content in the orchard's soil.

Furthermore, the use of different functional units may result in deviating results. This review of literature shows that a simple mass-based functional unit is not always able to represent the full complexity of the environmental impacts of orchard systems. Therefore it may be necessary to use combined functional units or other functional units. For example, a land use-based functional unit can be used with a mass-based functional unit in order to present a more complete picture and avoid resource use efficiency overvaluation and a dislocation of environmental impacts. As a general remark, when a mass-based functional unit is chosen, the quantity of edible content within the unit should always be indicated. Indeed, this parameter is necessary to scale environmental impacts exclusively to the quantity actually consumed (BassetMens et al., 2010) for diet studies and product comparisons.

\section{Conclusions}

This review has been based on peer-reviewed studies of LCA applications on fruit production systems all over the world. Although the papers' general shared aim was to evaluate the environmental performance of specific fruit production systems, there were several different aims across these studies as well as significant heterogeneity in terms of methodological choices.

One of the most crucial aspects in the assessment is that most of the LCA studies reviewed assess perennial systems in the same way as annual crops, therefore considering just one productive year within the time boundaries of the system. This problem gives an inadequate view of the quality of the orchard model and, possibly, miscalculates the real environmental impact potentials of the production system. Therefore a general orchard model was developed to include the whole lifetime of the system and practical recommendations are proposed in this paper. The orchard model described should be helpful in initiatives to produce an international standardisation of methods such as the ENVIFOOD protocol.

Further studies should focus on:

(I) including the multi-functionality of orchard systems in the environmental assessment. In particular in relation to the fact that orchards might have several functions other than fruit production, such as preserving the genetic heritage (Donno et al., 2012) and traditional landscapes (Biasi et al., 2010). Furthermore trees are often grown in association with other horticultural crops, especially in tropical areas, and the use of specific allocation methods or system expansion approaches should be discussed and validated

(II) modelling the role of orchards as sinks for $\mathrm{CO}_{2}$ sequestration. Indeed orchards, if properly managed, may have great potential for the absorption and net storage of $\mathrm{CO}_{2}$ (Sofo et al., 2005) that might significantly affect results in the Global Warming Potential category (Bosco et al., 2013). A discussion about how to account for carbon sequestration and temporary storage in an LCA was recently presented by Brandão et al. (2013), but specific models for orchard systems are not included.

(III) Consolidating results from harmonisation initiatives. As highlighted in Section 4, different initiatives have suggested alternative settings for LCA applications in fruit production systems. In particular it might be interesting to have case 


\section{studies in which results are validated and compared using recommendations from EPD $^{\circledR}$, either from the EnviFood protocol or other references.}

\section{References}

ADEME, 2010. La méthode Bilan Carbone ${ }^{\circledR}$. Agence de L'Environnement et de la Maîtrise de l'Energie. Available from: www2.ademe.fr.

Basset-Mens, C., Benoist, A., Bessou, C., Tran, T., Perret, S., Vayssières, J., Wassenaar, T. 2010. Is LCA-based eco-labeling reasonable? The issue of tropical food products. In: 7th International Conference on Life Cycle Assessment in the Agri-Food Sector, Bari, Italy, vol. 1, pp. 461-466.

Beccali, M., Cellura, M., Iudicello, M., Mistretta, M., 2009. Resource consumption and environmental impacts of the agrofood sector: life cycle assessment of Italian citrus-based products. Environ. Manag. Springer New York 43, 707-724.

Beccali, M., Cellura, M., Iudicello, M., Mistretta, M., 2010. Life cycle assessment of Italian citrus-based products. Sensitivity analysis and improvement scenarios. J. Environ. Manag. 91, 1415-1428.

Berners-Lee, M., Hoolohan, C., Cammack, H., Hewitt, C.N., 2012. The relative greenhouse gas impacts of realistic dietary choices. Energy Policy 43, 184-190.

Bessou, C., Basset-Mens, C., Tran, T., Benoist, A., 2013. LCA applied to perennial cropping systems: a review focused on the farm stage. Int. J. Life Cycle Assess. Springer Berlin/Heidelberg 18, 340-361.

Biasi, R., Botti, F., Barbera, G., Cullotta, S., 2010. The role of Mediterranean fruit tree orchards and vineyards in maintaining the traditional agricultural landscape. ISHS Acta Hortic. 940, 79-88.

Birkved, M., Hauschild, M.Z., 2006. PestLCI-a model for estimating field emissions of pesticides in agricultural LCA. Ecol. Model. 198, 433-451.

Blanke, M., Burdick, B., 2005. Food (miles) for thought - energy balance for locallygrown versus imported apple fruit (3 pp). Environ. Sci. Pollut. Res. Int. Springer Berlin/Heidelberg 12, 125-127.

Bosco, S., Di Bene, C., Galli, M., Remorini, D., Massai, R., Bonari, E., 2013. Soil organic matter accounting in the carbon footprint analysis of the wine chain. Int. J. Life Cycle Assess. Springer Berlin/Heidelberg 18, 973-989.

Brandão, M., Levasseur, A., Kirschbaum, M.U.F., Weidema, B.P., Cowie, A.L., Jørgensen, S.V., Hauschild, M.Z., Pennington, D.W., Chomkhamsri, K., 2013. Key issues and options in accounting for carbon sequestration and temporary storage in life cycle assessment and carbon footprinting. Int. J. Life Cycle Assess. Springer Berlin/Heidelberg 18, 230-240.

BSI, 2011. PAS 2050 Specification for the Assessment of the Life Cycle Greenhouse Gas Emissions of Goods and Services. British Standards, London, UK.

Carbon Trust, 2007. Carbon Footprint Measurement Methodology. The Carbon Trust, London, UK.

Carlsson-Kanyama, A., Ekström, M.P., Shanahan, H., 2003. Food and life cycle energy inputs: consequences of diet and ways to increase efficiency. Ecol. Econ. 44, 293-307.

Cerutti, A.K., Bagliani, M., Beccaro, G.L., Peano, C., Bounous, G., 2010. Comparison of LCA and EFA for the environmental account of fruit production systems: a case study in Northern Italy. In: Notarnicola, B., Settanni, E., Tassielli, G., Giungato, P. (Eds.), Proceedings of LCA Food 2010. Bari, pp. 99-104.

Cerutti, A.K., Galizia, D., Bruun, S., Mellano, G.M., Beccaro, G.L., Bounous, G., 2011. Assessing environmental sustainability of different apple supply chains in Northern Italy. In: Finkbeiner, M. (Ed.), Towards Life Cycle Sustainability Management. Springer, Netherlands, Dordrecht, pp. 341-348.

Cerutti, A.K., Bruun, S., Donno, D., Beccaro, G.L., Bounous, G., 2013. Environmental sustainability of traditional foods: the case of ancient apple cultivars in Northern Italy. J. Clean. Prod. 52, 245-252.

Clasadonte, M.T., Matarazzo, A., Ingrao, C., 2010a. Life cycle assessment of Sicilian peach sector. In: Notarnicola, B., Settanni, E., Tassielli, G., Giungato, P. (Eds.), Proceedings of LCA Food 2010. Bari, pp. 295-300.

Clasadonte, M.T., Lo Giudice, A., Ingrao, C., 2010b. Life Cycle Assessment of the Sicilian citrus fruit field. In: Notarnicola, B., Settanni, E., Tassielli, G., Giungato, P. (Eds.), Proceedings of LCA Food 2010. Bari, pp. 301-306.

Coltro, L., Mourad, A.L., Kletecke, R.M., Mendonça, T.A., Germer, S.P.M., 2009. Assessing the environmental profile of orange production in Brazil. Int. J. Life Cycle Assess. Springer Berlin/Heidelberg 14, 656-664.

Cudjoe Adebah, E., Langeveld, C., Kermah, M., 2010. Environmental Impact of Organic Pineapple Production in Ghana: a Comparison of Two Farms Using Life Cycle Assessment (LCA) Approach.

De Camillis, C., Bligny, J.C., Pennington, D., Pályi, B., 2012. Outcomes of the second workshop of the Food Sustainable Consumption and Production Round Table Working Group 1: deriving scientifically sound rules for a sector-specific environmental assessment methodology. Int. J. Life Cycle Assess. Springer Berlin/Heidelberg 17, 511-515.

Del Borghi, A., 2013. LCA and communication: environmental product declaration. Int. J. Life Cycle Assess. Springer Berlin/Heidelberg 18, 293-295.

Dijkman, T.J., Birkved, M., Hauschild, M.Z., 2012. PestLCI 2.0: a second generation model for estimating emissions of pesticides from arable land in LCA. Int. J. Life Cycle Assess. Springer Berlin/Heidelberg 17, 973-986.

Donno, D., Beccaro, G.L., Mellano, M.G., Torello Marinoni, D., Cerutti, A.K., Canterino, S., Bounous, G., 2012. Application of sensory, nutraceutical and genetic techniques to create a quality profile of ancient apple cultivars. J. Food Qual. 35 (3), 169-181.
European Commission, 2010. The International Reference Life Cycle Data System (ILCD) Data Network - Compliance Rules and Entry-level Requirements. European Commission, DG-JRC.

European Commission, 2012. Environmental Assessment of Food and Drink Protocol. Draft Version 0.1 for Pilot Testing November 2012. European Food Sustainable Consumption and Production Roundtable.

European Commission, 2013. Product Environmental Footprint (PEF) Guide. European Commission. DG-JRC Ref. Ares(2012)873782-17/07/2012.

FAOSTAT, 2012. World Food and Agriculture Database. (accessed December 2012) at: http://faostat.fao.org.

Gutsche, V., Rossberg, D., 1997. SYNOPS 1.1: a model to assess and to compare the environmental risk potential of active ingredients in plant products. Agric. Ecosyst. Environ. 64, 181-188.

Hauschild, M.Z., 2000. Estimating pesticide emissions for LCA of agricultural products. In: Weidema, B.P., Meeusen, M.J.G. (Eds.), Agricultural Data for Life Cycle Assessments, vol. 2. LCANet Food, The Hague, The Netherlands, pp. 64-79.

Hayashi, K., 2013. Practical recommendations for supporting agricultural decisions through life cycle assessment based on two alternative views of crop production: the example of organic conversion. Int. J. Life Cycle Assess. Springer Berlin/ Heidelberg 18, 331-339.

Ingram, D.L., 2012. Life cycle assessment of a field-grown red maple tree to estimate its carbon footprint components. Int. J. Life Cycle Assess. Springer Berlin/Heidelberg 17, 453-462.

Ingwersen, W., 2010. Product category range of environmental performance for EPDs: example of Costa Rican pineapple. In: Notarnicola, B., Settanni, E., Tassielli, G., Giungato, P. (Eds.), Proceedings of LCA Food 2010. Bari, pp. 337-341.

Ingwersen, W., Stevenson, M.J., 2012. Can we compare the environmental performance of this product to that one? An update on the development of product category rules and future challenges toward alignment. J. Clean. Prod. 24, 102-108.

ISO, 2013b. ISO/DIS 14046 Environmental Management - Water Footprint - Principles, Requirements and Guidelines.

ISO, 2013a. ISO/TS 14067 Greenhouse Gases - Carbon Footprint of Products - Requirements and Guidelines for Quantification and Communication.

Knudsen, M.T., Fonseca de Almeida, G., Langer, V., Santiago de Abreu, L., Halberg, N., 2011. Environmental assessment of organic juice imported to Denmark: a case study on oranges (Citrus sinensis) from Brazil. Org. Agri. Springer Netherlands 1,167-185.

Liu, Y., Langer, V., Høgh-Jensen, H., Egelyng, H., 2010. Life Cycle Assessment of fossil energy use and greenhouse gas emissions in Chinese pear production. J. Clean. Prod. 18, 1423-1430.

McLaren, S.J., Hume, A., Mithraratne, N., 2010. Carbon management for the primary agricultural sector in New Zealand: case studies for the pipfruit and kiwifruit industries. In: Notarnicola, B., Settanni, E., Tassielli, G., Giungato, P. (Eds.), Proceedings of LCA Food 2010, pp. 293-298.

Milà I Canals, L., Burnip, G.M., Cowell, S.J., 2006. Evaluation of the environmenta impacts of apple production using Life Cycle Assessment (LCA): case study in New Zealand. Agric. Ecosyst. Environ. 114, 226-238.

Milà i Canals, L., Cowell, S.J., Sim, S., Basson, L., 2007. Comparing domestic versus imported apples: a focus on energy use. Environ. Sci. Pollut. Res. Int. Springer Berlin/Heidelberg 14, 338-344.

Mouron, P., Scholz, R.W., Nemecek, T., Weber, O., 2006a. Life cycle management on Swiss fruit farms: relating environmental and income indicators for fruit growing. Ecol. Econ. 58, 561-578.

Mouron, P., Nemecek, T., Scholz, R.W., Weber, O., 2006b. Management influence on environmental impacts in an apple production system on Swiss fruit farms: combining life cycle assessment with statistical risk assessment. Agric. Ecosyst. Environ. 114, 311-322.

Mouron, P., Heijne, B., Naef, A., Strassemeyer, J., Hayer, F., Avilla, J., Alaphilippe, A., Höhn, H., Hernandez, J., Gaillard, G., Mack, G., Solé, J., Sauphanor, B., Samietz, J., Patocchi, A., Bravin, E., Lavigne, C., Bohanec, M., Aubert, U., Bigler, Franz, 2012. Sustainability assessment of crop protection systems: SustainOS methodology and its application for apple orchards. Agric. Syst. 113, 1-15.

Nemecek, T., Huguenin-Elie, O., Dubois, D., Gaillard, G., Schaller, B., Chervet, A., 2011. Life cycle assessment of Swiss farming systems: II. Extensive and intensive production. Agric. Syst. 104, 233-245.

Notarnicola, B., Tassielli, G., Renzulli, P.A., 2012a. Modeling the agri-food industry with Life Cycle Assessment. In: Curran, M. (Ed.), Life Cycle Assessment Handbook: a Guide for Environmentally Sustainable Products. Wiley, Scrivene Publishing, Salem, MA.

Notarnicola, B., Hayashi, K., Curran, M.A., Huisingh, D., 2012b. Progress in working towards a more sustainable agri-food industry. J. Clean. Prod. 28, 1-8.

Notarnicola, B., Tassielli, G., Renzulli, P.A., 2013. La variabilità dei dati nella LCA della produzione olivicola. In: Proceedings of the VII Congress of the Italian LCA Network, ISBN 978-88-8286-292-3, pp. 29-35.

Peacock, N., De Camillis, C., Pennington, D., Aichinger, H., Parenti, A., Rennaud, J. Raggi, A., Brentrup, F., Sára, B., Schenker, U., Unger, N., Ziegler, F., 2011. Towards a harmonised framework methodology for the environmental assessment of food and drink products. Int. J. Life Cycle Assess. Springer Berlin/Heidelberg 16, 189-197.

Petti, L., Ardente, F., Bosco, S., De Camillis, C., Masotti, P., Pattara, C., Raggi, A. Tassielli, G., 2010. State of the art of Life Cycle Assessment in the wine industry. In: Notarnicola, B., Settanni, E., Tassielli, G., Giungato, P. (Eds.), Proceedings of LCA Food 2010. Bari, vol. 1, pp. 493-498.

Pirilli, M., Falcone, G., Strano, A., 2012. La formazione dell'inventario per l'LCA nei confronti fra processi produttivi agricoli nella clementinicoltura in Calabria. In: Proceedings of the VI Congress of the Italian LCA Network, Bari, 7-8 June, 2012. 
Russo, G., Scarascia-Mugnozza, G., 2005. LCA methodology applied to various typology of greenhouses. Acta Hortic. 691, 837-843.

Sanjuan, N., Ubeda, L., Clemente, G., Mulet, A., Girona, F., 2005. LCA of integrated orange production in the Comunidad Valenciana (Spain). Int. J. Agric. Resour Gov. Ecol. 4 (2), 163-177.

Sansavini, S., Costa, G., Gucci, R., Inglese, P., Ramina, A., Xiloyannis, C. (Eds.), 2012 Arboricoltura generale. Pàtron Editore Bologna, Italy.

Sim, S., Barry, M., Clift, R., Cowell, S.J., 2007. The relative importance of transport in determining an appropriate sustainability strategy for food sourcing. Int. J. Life Cycle Assess. Springer Berlin/Heidelberg 12, 422-431.

Sofo, A., Nuzzo, V., Palese, A.M., Xiloyannis, C., Celano, G., Zukowskyj, P., Dichio, B. 2005. Net $\mathrm{CO}_{2}$ storage in Mediterranean olive and peach orchards. Sci. Horticult. $107,17-24$.

Strassemeyer, J., Gutsche, V., 2010. The approach of the German pesticide risk indicator SYNOPS in the frame of the national action plan on the sustainable use of pesticides. In: OECD Workshop on Agri-Environmental Indicators, Leysin, Switzerland. http://www.oecd.org/dataoecd/32/16/GGTSPU-styx2.bba. de-11619-4690407-DAT/44806454.pdf.

van der Werf, H.M.G., Petit, J., 2002. Evaluation of the environmental impact of agriculture at the farm level: a comparison and analysis of 12 indicator-based methods. Agric. Ecosyst. Environ. 93, 131-145. van der Werf, H.M.G., Tzilivakis, J., Lewis, K., Basset-Mens, C., 2007. Environmental impacts of farm scenarios according to five assessment methods. Agric. Ecosyst. Environ. 118, 327-338.

Wackernagel, M., Rees, W., 1997. Perceptual and structural barriers to investing in natural capital: economics from an ecological footprint perspective. Ecol. Econ. 20 (1), 3-24.

Wallén, A., Brandt, N., Wennersten, R., 2004. Does the Swedish consumer's choice of food influence greenhouse gas emissions? Environ. Sci. Policy 7, 525-535.

Williams, A., Pell, E., Webb, J., Moorhouse, E., Audsley, E., 2008. Strawberry and tomato production for the UK compared between the UK and Spain. In: Proceedings of the 6th International Conference on LCA in the Agri-food Sector, pp. 254-262.

WBCSD/WRI, 2009. The Greenhouse Gas Protocol. A Corporate Accounting and Reporting Standard. World Resources Institute-World Business Council for Sustainable Development, Washington, DC, USA.

Yusoff, S., Hansen, S.B., 2007. Feasibility study of performing a life cycle assessment on crude palm oil production in Malaysia. Int. J. Life Cycle Assess. Springer Berlin/Heidelberg 12, 50-58.

Zackrisson, M., Rocha, C., Christiansen, K., Jarnehammar, A., 2008. Stepwise environmental product declaration: ten SME case studies. J. Clean. Prod. 16, 18721886. 